\title{
Pengaruh pembelajaran manajemen keuangan terhadap perilaku berinvestasi yang dimoderasi gender
}

\author{
Masno Marjohan*) \\ Universitas Pamulang, Indonesia
}

\begin{tabular}{l} 
Article Info \\
\hline Article history: \\
Received Mar $12^{\text {th }}, 2021$ \\
Revised Apr $20^{\text {th }}, 2021$ \\
Accepted May $26^{\text {th }}, 2021$ \\
\hline
\end{tabular}

\section{Keyword:}

Gender

Financial management

Investment behavior

\begin{abstract}
The purpose of this study was to analyze the effect of learning financial management on investment behavior of Master of Management students at Pamulang University and to determine the effect of learning financial management on investment behavior moderated by gender. This research is an applied research type with a descriptive statistical verification approach. The population is Master of Management students class 2018 and 2019, sampling using purposive sampling so that the number of samples is 100 respondents. Data analysis using path analysis method using SmartPLS program. Data processing techniques using SEM method based on Partial Least Square (PLS). The results showed that there was an effect of financial management learning on investment behavior of Pamulang University Master of Management students, gender variable could not moderate the effect of financial management learning on investment behavior of Pamulang University Master of Management students.
\end{abstract}

C 2021 The Authors. Published by IICET.

This is an open access article under the CC BY-NC-SA license (https://creativecommons.org/licenses/by-nc-sa/4.0)

\section{Corresponding Author:}

Masno Marjohan,

Universitas Pamulang, Indonesia

Email: dosen00124@unpam.ac.id

\section{Pendahuluan}

Tren investor di berbagai pasar modal, termasuk Indonesia, telah bergeser dari baby boomer yang memiliki kekayaan, jadi mereka mampu melakukan kegiatan investasi, untuk ranah milenial yang sebagian besar adalah mahasiswa dengan usia yang relatif muda. The Pew research center memperkirakan bahwa jumlah pasar modal investor dari generasi milenial memiliki meningkat menjadi 73 juta, sedangkan baby boomer telah menurun 72 juta pada tahun 2019 (Keuangan.yahoo.com, 2019). Sebagian besar investor milenial adalah mahasiswa. Setiap tahun jumlah investor mahasiswa meningkat, terutama di pasar saham. Siswa yang berinvestasi di pasar saham memiliki tujuan yang sama dengan investor secara umum, yang diharapkan di masa depan pengembalian investasi dalam bentuk dividen dan keuntungan modal (Croushore, 2006). Minat investasi di Indonesia semakin meningkat setiap tahunnya (Maghfiroh, Purnamawati, 2021)

Dalam mencapai tujuannya, siswa perlu lebih baik pengetahuan dan pemahaman tentang produk ditawarkan oleh pasar modal sebagai pemain baru dengan pengalaman terbatas untuk menghindari kekeliruan keputusan investasi. Lihat konvensional teori keuangan, investor sangat rasional dan bertindak untuk memaksimalkan kekayaan dalam investasi mereka keputusan (Markowitz, 1952), tetapi ketika mereka membuat keputusan investasi dalam kehidupan nyata, itu tampaknya investor sering berperilaku tidak rasional (Rasheed, dkk. 2016). Perilaku ini sebagian disebabkan rendahnya literasi pasar modal yang akan mempengaruhi aspek psikologis saat membuat keputusan investasi 
Perilaku investasi adalah tindakan atau perbuatan tidak mengkonsumsi sebagian pendapatan yang diperoleh rumah tangga saat ini dan ditahan dalam kurun waktu tertentu untuk mendapatkan manfaat di masa yang akan datang dan dirupakan dalam bentuk asset tertentu (Widayat, 2011). Faktor-faktor yang memengaruhi perilaku investor individu adalah faktor demografi seperti pendidikan, fundamental saham, karakteristik gaya hidup, pengaruh psikologis, nilai-nilai pribadi, penasihat professional, kebutuhan keuangan pribadi, risk tolerance, informasi dan faktor lain (Janor, Yakob, Hashim, Zanariah, \& Wel, 2016).

Program studi Magister Manajemen Universitas Pamulang adalah salah satu program studi yang memberikan pengetahuan mengenai investasi kepada mahasiswa untuk meningkatkan minat berinvestasi mahasiswa. Inilah mengenai investasi pasar modal juga bukan hal yang asing bagi mahasiswa program studi Manajemen, khususnya bagi mahasiswa konsentrasi manajemen keuangan karena konsentrasi manajemen keuangan merupakan konsentrasi yang paling sering membahas mengenai investasi pasar modal khususnya saham.

Berdasarkan survey pendahuluan berupa kuisioner terhadap 30 (tiga puluh) orang mahasiswa jurusan Manajemen Universitas Pamulang angkatan 2018 dan 2019, diperoleh data mengenai mahasiswa terhadap penentu perilaku dalam berinvestasi yaitu:

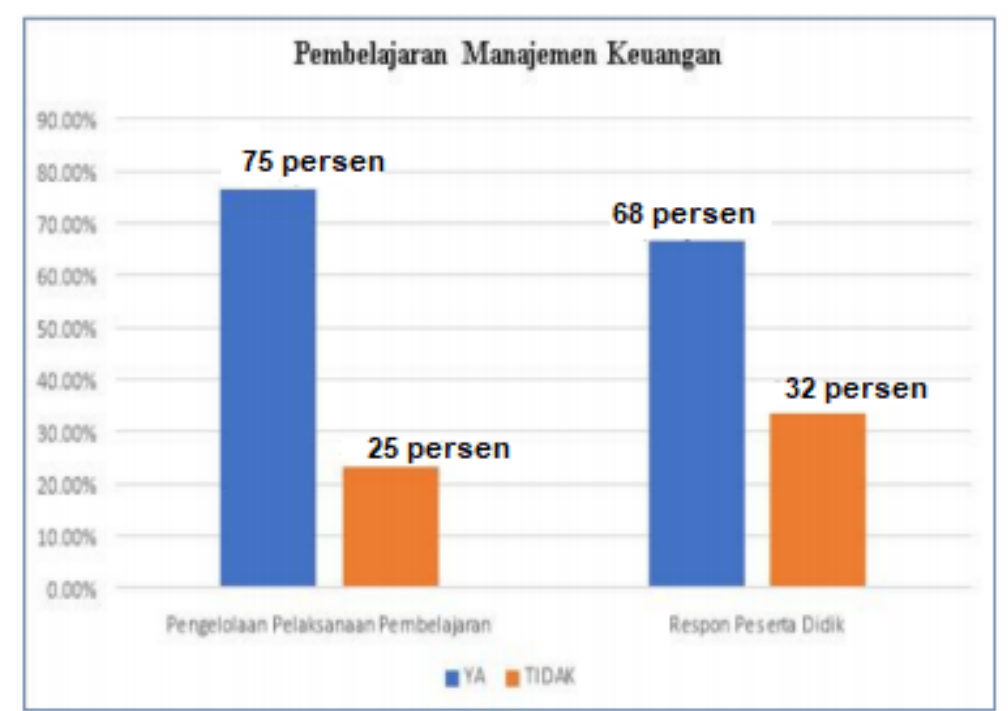

Gambar 1. Data Pembelajaran Manajemen Keuangan Mahasiswa Jurusan Manajemen Magister Manajemen Universitas Pamulang

Gambar 1 menunjukan bahwa pada variabel pembelajaran manajemen keuangan mahasiswa, berdasarkan aspek dalam pengelolaan pelaksanaan pembelajaran didapat bahwa jawaban ya dengan persentase 75 persen dan sisanya memilih jawaban tidak dengan persentase 25 persen. Berdasarkan pada persentase tersebut menunjukan mahasiswa akan memahami manajemen keuangan dengan baik setelah mendapatkan pembelajaran mengenai manajemen keuangan. sementara aspek respon peserta didik disimpulkan dengan jawaban ya sebesar 68 persen dan memilih jawaban tidak sebesar 32 persen. Dengan demikian mahasiswa akan mengetahui tentang investasi setelah belajar manajemen keuangan.

Sejalan dengan perkembangan pemikiran, munculah teori dimana dalam pengambilan keputusan tidak selalu bersifat rasional. Dalam bidang ekonomi, dikembangkan kajian perilaku yang menekankan pada penjelasan dan pemahaman pola perilaku keputusan investasi dimana terdapat proses psikologis yang mempengaruhi (Widayat, 2011). Paham mengenai keuangan juga tidak selalu dijadikan sebagai acuan untuk mengambil keputusan, sehingga seringkali mengalami perkiraan yang salah (Pradikasari \& Isbanah, 2018). Investor mahasiswa seringkali melakukan tindakan yang irasional. Tindakan yang dilakukan oleh mahasiswa tidak selalu disertai dengan teori keuangan (Pradikasari \& Isbanah, 2018).

Sementara gender diidentifikasi sebagai salah satu faktor yang mempengaruhi perilaku keuangan mahasiswa. Beberapa studi mengungkapkan bahwa laki-laki lebih pandai dalam mengelola keuangan dibandingkan dengan perempuan (Ansong dan Gyensare, 2012, Taylor dan Wegland, 2009). Hal ini mengindikasikan bahwa laki-laki lebih memiliki kepercayaan yang tinggi dalam membuat keputusan keuangan dibandingkan dengan perempuan yang lebih cenderung risk averse dibandingkan dengan laki-laki. Lebih lanjut, Wagland dan Taylor (2009) menambahkan bahwa rendahnya kepercaan diri perempuan juga 
disebabkan oleh peranannya sebagai ibu rumah tangga sekaligus career woman sehingga sulit sekali untuk menabung. Perempuan cenderung kurang bisa mengendalikan masalah keuangan dibandingkan dengan lakilaki. Hal ini mengindikasikan bahwa laki-laki dan perempuan memiliki motivasi yang berbeda dalam hal keuangan. (Yulinar, Puji, Nurvitasari, 2020)

Menurut WHO (World Health Organization) gender, yaitu "seperangkat peran, perilaku, kegiatan, dan atribut yang dianggap layak bagi laki-laki dan perempuan, yang dikonstruksikan secara sosial dalam masyarakat." Gender berbeda dengan jenis kelamin yang bersifat biologis, meskipun dalam pembicaraan sehari-hari dianggap sama. Gender diartikan suatu sifat yang terdapat pada laki-laki dan perempuan yang terbentuk secara sosial dan budaya. Oleh karenanya, muncul anggapan bahwa perempuan itu mempunyai sifat yang lemah lembut, cantik, emosional, dan keibuan. Sedangkan laki-laki mempunyai pribadi yang memiliki karakteristik yang kuat, rasional, dan perkasa. Teori Gender Adapun teori gender menurut Sri Sundari Sasongko (2009) adalah sebagai berikut: 1) Teori Nurture, adanya perbedaan antara laki-laki dan perempuan yang pada hakikatnya akan menghasilkan kontruksi sosial budaya sehingga menghasilkan peran dan tugas yang berbeda; 2) Teori Nature, teori ini berbicara tentang adanya perbedaan perempuan dan lakilaki dari kodrat yang diberikan sehingga tidak dapat berubah dan bersifat universal; 3) Teori Equilibrum, merupakan pemahaman kompromistis yang sering dikenal dengan keseimbangan (equilibrium) yang menekankan pada konsep kemitraan dan keharmonisan dalam hubungan antara perempuan dan laki-laki.

Semakin tingginya tingkat pendidikan akan meluaskan pengetahuan dalam berbagai bidang, khususnya dalam bidang keuangan sehingga paham dalam melakukan pengambilan keputusan investasi. Salah satu tingkat pendidikan adalah di perguruan tinggi. Pembelajaran di perguruan tinggi negeri didapatkan oleh mahasiswa melalui pelajaran yang telah diterima saat melakukan perkuliahan. Hermawati \& Mudhofar (2018) mengatakan bahwa pembelajaran investasi merupakan pemahaman aspek-aspek tentang investasi baik pengetahuan dasar penilaian investasi, tingkat resiko, dan tingkat pengembalian yang harus dimiliki individu. Sedangkan dalam penelitian Cahya \& Wahono (2017) pembelajaran tidak berpengaruh positif terhadap keputusan investasi.

Manajemen keuangan dalam arti luas merupakan keseluruhan aktivitas perusahaan yang berkaitan dengan usaha untuk mendapatkan dana (obtaining of funds) yang diperlukan dengan biaya yang minimal dan syaratsyarat yang paling menguntungkan beserta usaha untuk menggunakan atau mengalokasikan dana tersebut (use/allocation of funds) seefisien mungkin. Dalam arti yang lebih sempit, manajemen keuangan adalah aktivitas yang hanya berkaitan dengan usaha mendapatkan dana saja, yang sering juga dinamakan pembelanjaan pasif atau pendanaan (financing). Dengan demikian, manajemen keuangan tidak lain adalah manajemen untuk fungsi-fungsi pembelanjaan. Dalam pengertian manajemen terkandung fungsi-fungsi perencanaan, pengarahan, dan pengendalian. Berkaitan dengan itu, maka perlu ada perencanaan dan pengendalian yang baik dalam menggunakan maupun dalam pemenuhan kebutuhan dana (Syahyunan, 2015).

Pembelajaran manajemen keuangan sangat berhubungan erat dengan pendidikan. Dengan adanya pembelajaran manajemen keuangan, seorang mahasiswa pasti mendapat banyak wawasan tentang teori keuangan, pengelolaan keuangan, cara berinvestasi yang baik dan masih banyak lagi. Menurut Tanusdjaja (2018) dalam menentukan jenis investasi hal yang sangat penting adalah pendidikan. Dengan adanya pendidikan dapat membentuk diri individu, tingginya tingkat pendidikan akan menentukan tingkat bijaknya seseorang dalam pengambilan keputusan dan banyaknya pengalaman dalam pengetahuan mengenai keuangan. Semakin tingginya tingkat pendidikan keuangan juga akan memperdalam pengetahuan dalam bidang keuangan, sehingga paham dalam melakukan keputusan investasi dan dapat beperilaku berinvestasi yang baik dan benar..

Berdasarkan latar belakang, maka secara khusus pembahasan penelitian yang menjadi rumusan masalah, yaitu bagaimana pengaruh pembelajaran manajemen terhadap perilaku berinvestasi pada mahasiswa Magister Manajemen Universitas Pamulang serta apakah Gender dapat memoderasi pengaruh pembelajaran manajemen keuangan terhadap keputusan berinvestasi pada mahasiswa Magister Manajemen Universitas Pamulang?

\section{Method}

Jenis penelitian ini adalah penelitian terapan dengan pendekatan statistik deskriptif. Data yang digunakan dalam penelitian ini adalah data primer, penelitian ini diperoleh dari pengumpulan data yang dilakukan dengan menyebarkan kuisioner. Instrumen penelitian ditetapkan berdasarkan hasil observasi, telaah literatur, pendapat pihak-pihak yang berkaitan serta pengolahan data secara kuantitatif. Penelitian ini juga menggunakan informasi tambahan yaitu dibutuhkan diperoleh dari artikel, jurnal, teks buku dan lain-lain. 
Populasi dalam penelitian ini adalah mahasiswa Manajemen manajemen angkatan 2018 dan 2017 Universitas Pamulang, Penentuan jumlah sampel menggunakan pendekatan teknik purposive sampling dimana elemen sampel objek yang diteliti dipilih berdasarkan pertimbangan dan criteria tertentu yaitu dengan toleransi kesalahan sebesar 10\% yaitu sebanyak 100 responden yang akan diteliti (Sugiyono 2008;Cooper dan Emory; 1996). Penentuan sampel harus memenuhi kriteria sebagai berikut (1). Sampel dibatasi pada mahasiswa yang masih aktif di perkuliahan.(2). Sampel dibatasi pada mahasiswa yang sudah menempuh mata kuliah manajemen keuangan. (3). Sampel dibatasi pada mahasiswa yang telah mengambil kelas pasar modal dan (4). Sampel dibatasi pada mahasiswa yang telah melakukan investasi.

Teknik analisis ini secara spesifik digunakan untuk mengetahui kelayakan peranan variabel moderasi dari model yang dikembangkan. Adapun pengujian dari penelitian ini dilakukan dengan menggunakan program SmartPLS.Teknik pengolahan data dengan menggunakan metode SEM berbasis Partial Least Square (PLS) memerlukan 2 tahap untuk menilai Fit Model dari sebuah model penelitian. Ghozali (2006) menjelaskan tahapan dalam mengembangkan model tersebut adalah sebagai berikut :

\section{Uji outer model (measurement model)}

Tahap pertama dalam smartPLS menilai outer model yaitu proses interaksi indikator dan variabel laten diperlukan sebagai deviasi (penyimpangan) dari nilai means (rata-rata) dengan tujuan melihat hubungan antar indikator dengan konstruknya. Terdapat tiga kriteria untuk menilai outer model yaitu convergent validity, discriminat validity dan composite reliability. Convergent validity dari model pengukuran dengan refleksif indikator dinilai berdasarkan korelasi antara item score/componen score yang dihitung dengan PLS. Ukuran refleksif individual dikatakan tinggi jika berkolerasi lebih dari 0.70 dengan konstruk yang diukur.

Discriminant validity dari model pengukuran dengan refleksif indikator dinilai berdasarkan cross loading pengukuran dengan konstruk. Metode lain untuk menilai discriminant validity adalah membandingkan niali root of average variance etracted (AVE) setiap konstruk dengan korelasi antara konstruk dengan konstruk lainnya dalam model. Jika nilai AVE setiap konstruk lebih besar dari pada nilai korelasi antar konstruk dengan konstruk lainnya dalam model ( $>0.50)$, maka dikatakan memiliki nilai discriminant validity yang baik. Untuk composite reliability kriteria layaknya dalam model ini yaitu jika nilai yang dihasilkan lebih besar dari 0.6.

\section{Uji inner model (structural model)}

Pengujian inner model atau model structural dilakukan untuk melihat hubungan antara konstruk, nilai signifikan dan Rsquare dari model penelitian. Model structural dievaluasi dengan menggunakan R-square untuk konstruk dependen dan uji-t serta signifikansi dari koefesien parameter jalur structural. Perubahan nilai $\mathrm{R}$-square dapat digunakan untuk menilai pengaruh variabel laten independen tertentu terhadap variabel laten dependen apakah mempunyai pengaruh substantive.

\section{Pengujian Hipotesis}

Pengujian hipotesis menggunakan analisis full model structural Equation modeling (SEM) dengan smart PLS. Dalam full model structural Equation modeling selain mengkonfirmasi teori, juga menjelaskan ada atau tidaknya hubungan antara variabel laten. Pengujian inner model atau model struktural dilakukan untuk melihat hubungan antara konstruk. Pengujian Inner model juga merupakan pengujian dari hubungan antar variabel laten. Karena prosedur PLS tidak memiliki nilai standar deviasi atau standar error dalam perhitungannya, maka pengujian ada tidaknya hubungan antar variabel dilakukan dengan menggunakan metode bootstrap.

Hasil signifikansi parameter yang diestimasi memberikan informasi yang sangat berguna mengenai hubungan antara variabel-variabel penelitian. Batas untuk menolak dan menerima hipotesis yang diajukan adalah $+1,96$, untuk $\mathrm{p}<0,05$ dimana apabila nilainilai $\mathrm{t}$ hitung $<\mathrm{t}$ tabel $(1,96)$ maka hipotesis alternatif $(\mathrm{Ha})$ akan ditolak atau dengan kata menerima hipotesis nol (H0).

\section{Hasil dan Pembahasan}

Pada tahapan evaluasi model yang dilakukan dalam mengidentifikasi hubungan antar konstruk laten yang dibentuk pada studi awal ini bertujuan untuk mengevaluasi kelayakan atas konstruk yang dibentuk, dan diharapkan mampu menghasilkan prediksi model yang lebih baik dalam mencapai luaran atas tujuan penelitian yang hendak dicapai. Untuk lebih jelasnya, berikut ilustrasi evaluasi model studi yang dilakukan yaitu sebagai berikut : 
Tabel 1. Hasil uji outer loading awal

\begin{tabular}{lcccc}
\hline & Gender & PMK & Moderating Effect & PK \\
\hline Gender & 1.000 & & & \\
PMK_1 & & 0.687 & & \\
PMK_2 & & 0.731 & & \\
PMK_3 & & 0.640 & & \\
PMK_4 & 0.871 & & \\
PMK_5 & 0.522 & & \\
PMK_6 & 0.631 & & \\
PMK_7 & 0.733 & & 0.725 \\
PMK_8 & 0.851 & & 0.634 \\
PMK*Gender & & & 0.834 \\
PI_1 & & & & 0.584 \\
PI_2 & & & \\
PI_3 & & & 0.645 \\
PI_4 & & & \\
PI_5 & & & \\
\hline
\end{tabular}

Tabel 1 diatas menjelaskan sebanyak 13 indikator dari setiap konstruk laten yang dibentuk terdapat 7 indikator pengukuran yang dinyatakan belum valid atau menprediksi terhadap laten model. Sedangkan tidak validnya indikator yang digunakan dalam melakukan prediksi atas konstruk laten model yang dibentuk disebabkan memiliki nilai hitung lebih kecil dari 0,7 namun pada hasil perhitungan ini jika nilai loading yang dihasilkan lebih besar atau sama dengan 0,7 masih dapat dipertimbangkan untuk digunakan dalam mengeksplor model yang akan diuji. Untuk lebih jelasnya berikut interpretasi pengolahan tahap 2 dari penelitian ini :

Tabel 2. Hasil Uji Outer Loading Akhir

\begin{tabular}{lcccc}
\hline & Gender & PMK & Moderating Effect & PK \\
\hline Gender & 1.000 & & & \\
PMK_2 & & 0.782 & & \\
PMK_4 & & 0.881 & & \\
PMK_7 & & 0.773 & & \\
PMK_8 & & 0.891 & & \\
PMK*Gender & & & & 0.065 \\
PI_1 & & & & 0.921 \\
PI_3 & & & & \\
\hline
\end{tabular}

Pada tabel 2 diatas secara keseluruhan item yang digunakan sudah memenuhi kriteria statistik yaitu setiap item dengan nilai loading yang dihasilkan lebih besar atau sama dengan 0,7 masih dapat dipertimbangkan untuk digunakan dalam mengeksplor model yang akan diuji. Kemudian relevansi hasil uji validitas konvergen yang dihasilkan melalui pendekatan hasil hitung average variance etracted (AVE) memiliki ilustrasi sebagai berikut :

Tabel 3. Hasil Uji Outer Loading Akhir

\begin{tabular}{ll}
\hline & AVE \\
\hline Gender & 1.000 \\
PMK & 0.637 \\
Moderating Effect & 1.000 \\
PI & 0.798 \\
\hline
\end{tabular}


Pada tabel 3 diatas menjelaskan seluruh variabel memiliki hasil hitung AVE lebih besar dari 0.5. maka dapat disimpulkan secara mayoritas rerata yang dihasilkan pada tahapan outer loading memiliki hubungan yang cukup kuat.

\section{Hasil Uji Validitas Diskriminan}

Pada hasil uji validitas diskriminan juga merupakan interpretasi refleksi hasil pengukuran cross loading terhadap konstruk laten yang akan dihasilkan yaitu melalui perbandingan akar AVE yang dihasilkan terhadap korelasi antara setiap konstruk laten yang dihasilkan (AVE). Untuk lebih jelasnya berikut interpretasi hasil uji akar AVE :

Tabel 4. Hasil Uji average variance etracted (AVE) dan Akar AVE

\begin{tabular}{lcc}
\hline & AVE & Akar AVE \\
\hline Gender & 1.000 & 1.000 \\
PMK & 0.637 & 0.798 \\
Moderating Effect & 1.000 & 1.000 \\
PI & 0.798 & 0.894 \\
\hline
\end{tabular}

Pada tabel 4 diatas memperlihatkan hasil uji validitas diskriminan memperlihatkan hasil hitung akar AVE yang memiliki nilai lebih besar dibandingkan dengan hasil hitung korelasi setiap konstruk laten yang diahasilkan (AVE). Untuk lebih jelasnya, berikut hasil uji korelasi dihasilkan pada penelitian ini yaitu sebagai berikut :

Tabel 5. Hasil Uji Fornell-Locker

\begin{tabular}{lcccc}
\hline & Gender & PMK & Moderating Effect & PI \\
\hline Gender & $\mathbf{1 . 0 0 0}$ & & & \\
PMK & -0.038 & $\mathbf{0 . 7 9 8}$ & & \\
Moderating Effect & 1.000 & -0.080 & $\mathbf{1 . 0 0 0}$ & $\mathbf{0 . 8 9 4}$ \\
PI & -0.071 & 0.602 & -0.060 & \\
\hline
\end{tabular}

Berdasarkan tabel 5 perbandingan nilai hitung akar AVE terhadap koefisien korelasi yang dihasilkan secara keseluruhan hasil uji korelasi berada dibawah hasil hitung akar AVE, artinya menunjukan bahwa model ini telah memenuhi kriteria validitas diskriminan

\section{Hasil uji reliabilitas}

Pada hasil uji ini bertujuan untuk memperlihatkan konsistensi keandalan atas setiap pengukuran indikator atau variabel yang akan digunakan. Lebih lanjut, berikut hasil uji reliabilitas seperti yang diungkapkan pada table 6.

Tabel 6. Hasil Uji Reliabilitas

\begin{tabular}{lcc}
\hline & Composite Reliability & Cronbachs Alpha \\
\hline Gender & 1.000 & 1.000 \\
PMK & 0.875 & 0.810 \\
Moderating Effect & 1.000 & 1.000 \\
PI & 0.888 & 0.751 \\
\hline
\end{tabular}

Berdasarkan tabel 6 menunjukan bahwa variabel bersifat reliabel dengan nilai hitung yang dihasilkan melalui cronbachs alpha $>0.6$ dan composite reliability lebih besar dari 0.7. Hal ini memperlihatkan secara umum variabel bersifat layak digunakan untuk mengukur model yang akan diuji.

\section{Pengujian Model Struktural (Structural Model)}

Pada hasil estimasi awal atas model struktural yang dibentuk pada studi ini akan memberikan ilustrasi hubungan pengaruh antar masing - masing konstruk laten yang dibentuk. Lebih lanjut berikut ilustrasi kausalitas hasil uji signifikansi antar konstruk laten model yang dibentuk, yaitu sebagai berikut: 


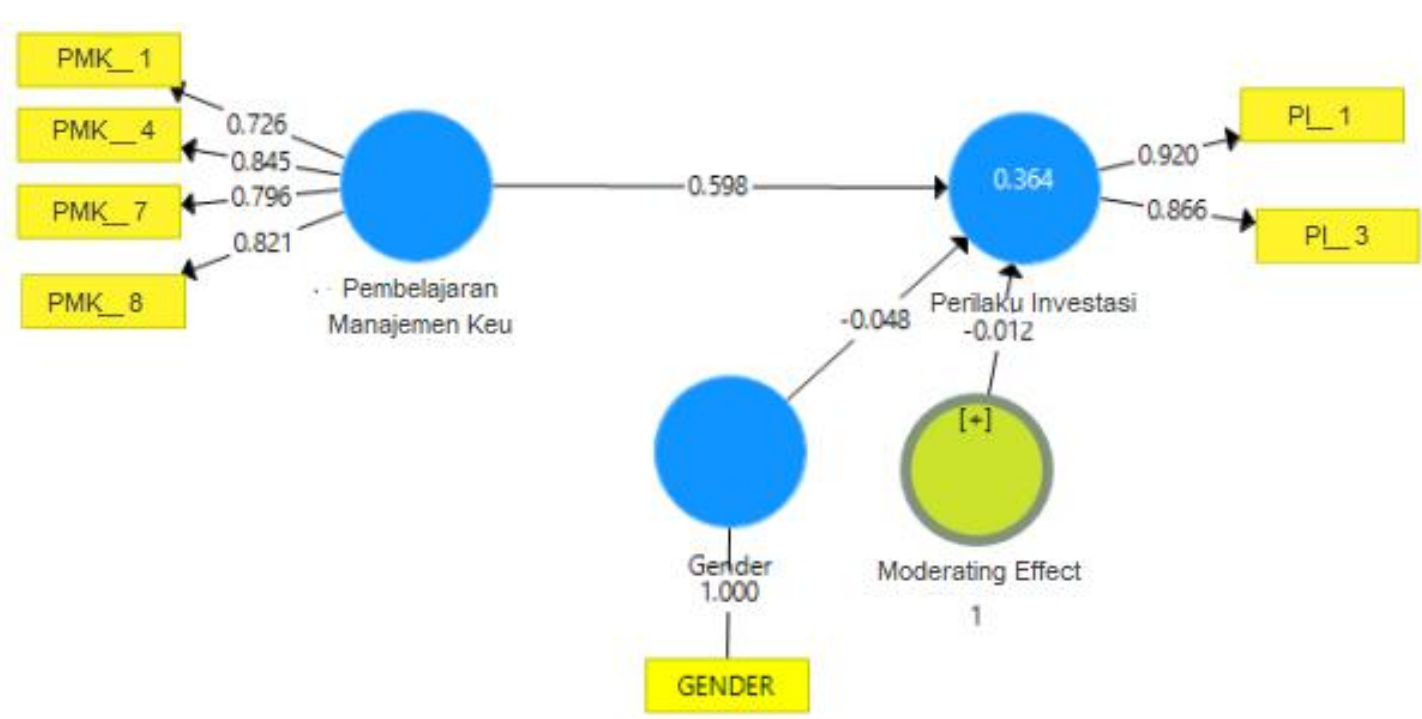

Gambar 2. Pengujian Model Struktural

Untuk lebih jelasnya, berikut interpretasi hubungan konstruk laten antar variabel yang diuji dapat dilihat pada ilustrasi table 7 sebagai berikut:

Tabel 7. Path Coefficients

\begin{tabular}{lccccc}
\hline & $\begin{array}{c}\text { Origninal } \\
\text { Sample (O) }\end{array}$ & $\begin{array}{c}\text { Sample } \\
\text { Mean } \\
\text { (M) }\end{array}$ & $\begin{array}{c}\text { Standar } \\
\text { Deviation } \\
\text { (STDV) }\end{array}$ & $\begin{array}{c}\text { T Statistic } \\
\text { (IO/STDVI) }\end{array}$ & P Values \\
\hline Gender ----> PI & -0.048 & -0.057 & 0.080 & 0.599 & 0.549 \\
PMK -----> PI & 0.598 & 0.593 & 0.097 & 6.189 & 0.000 \\
Moderating Effect -----> PI & -0.012 & -0.000 & 0.090 & 0.133 & 0.894 \\
\hline
\end{tabular}

Berdasarkan tabel 7 menjelaskan jalur Pembelajaran Manajemen Keuangan bersifat signifikan positif terhadap perilaku berinvestasi pada mahasiswa dengan nilai hitung yang dihasilkan lebih besar dari $1.96(\mathrm{n}=100, \alpha=$ $5 \%$ ). Namun variabel gender sebagai variabel moderating tidak memberikan pengaruh signifikan dalam mempengaruhi perilaku keuangan pada mahasiswa. Lebih lanjut, adapun hasil uji $\mathrm{R}$ square yang dihasilkan pada model penelitian ini yaitu sebagai berikut:

Tabel 8. Hasil R-Square

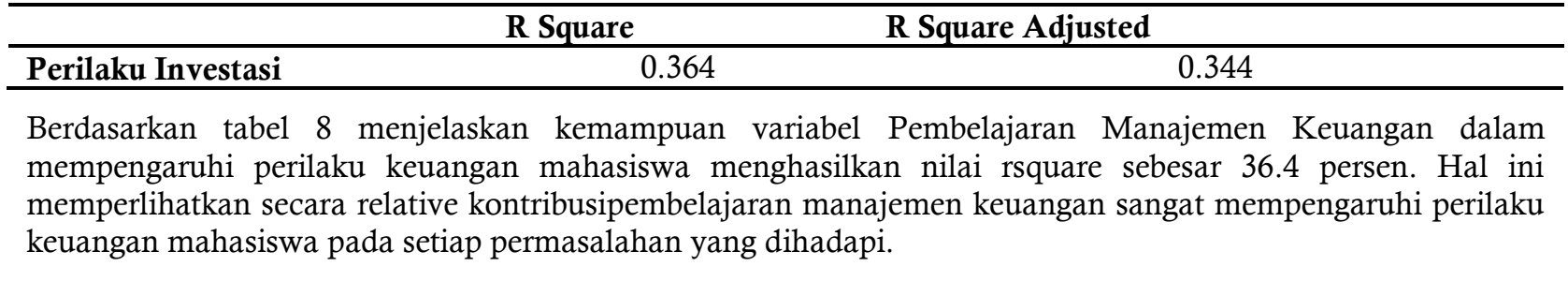

\section{Pengaruh pembelajaran manajemen keuangan terhadap perilaku keuangan dengan gender sebagai variabel} moderating

Pengaruh Pembelajaran Manajemen Keuangan terhadap Perilaku Berinvestasi Berdasarkan hasil penelitian bahwa pembelajaran manajemen keuangan berpengaruh positif dan signifikan terhadap perilaku berinvestasi mahasiswa Magister Manajemen Universitas Pamulang.

Direktorat tenaga kependidikan menjelaskan pembelajaran merupakan inti dari muara seluruh proses pengelolaan pendidikan. Pembelajaran merupakan suatu usaha seorang pendidik untuk mewujudkan proses pemerolehan pengetahuan, penguasaan kemahiran, pembentukan sikap, serta kepercayaan peserta didik (Hanafy, 2014). Pembelajaran yang aktif, efektif dan efisien dapat mengembangkan seluruh ranah dalam tujuan pembelajaran, yaitu ranah pengetahuan (kognitif), ranah sikap (afektif), dan ranah keterampilan (psiokomotrik). Salah satu ranah yang dapat dikembangkan dengan adanya pembelajaran yang aktif, efektif, dan efisien adalah ranah pengetahuan. Adapun mata kuliah manajemen keuangan merupakan mata kuliah 
yang dapat memberikan dorongan untuk memiliki perilaku investasi karena pada mata kuliah ini dapat memberikan pengetahuan akan investasi yang meliputi jenis investasi, return yang akan didapatkan, risiko yang akan diterima, dan hal-hal yang diperlukan oleh seseorang ketika melakukan pembelajaran manajemen keuangan yang baik akan diikuti dengan perilaku berinvestasi yang baik juga. Berdasarkan analisis data diketahui bahwa pembelajaran manajemen keuangan dapat dikategorikan baik dengan Dari hasil tersebut, mahasiswa menunjukkan bahwa pembelajaran manajemen keuangan sudah baik. Dengan pembelajaran yang baik dan efektif, akan memberikan pengetahuan kepada mahasiswa tentang investasi. Pengetahuan investasi tersebut yang nantinya akan digunakan oleh mahasiswa dalam melakukan investasi sehingga perilaku investasi mahasiswa tidak akan bersifat irasional. Hasil penelitian ini sesuai dengan penelitian yang telah dilakukan oleh Kumala (2019) yang mengatakan pembelajaran berpengaruh positif dan signifikan terhadap perilaku berinvestasi.

\section{Pengaruh pembelajaran manajemen keuangan terhadap perilaku keuangan dengan gender sebagai variabel} moderating

Berdasarkan hasil penelitian bahwa Variabel Gender tidak dapat memoderasi pengaruh pembelajaran Manajemen keuangan terhadap perilaku berinvestasi, Hal ini dapat disebabkan karena mahasiswa baik lakilaki maupun perempuan tidak asing lagi dengan hal yang berbau investasi. Mahasiswa laki-laki dan perempuan yang tergabung dalam kelompok studi pasar modal bersama-sama memahami dan mempelajari sesuatu yang baik untuk mendukung investasi mereka. Laki-laki dan perempuan memiliki kesempatan yang sama untuk melakukan kegiatan investasi mereka. Baik atau tidaknya investasi mereka tergantung kepada masing-masing individu. Bukan soal laki-laki ataupun perempuan, melainkan soal kemampuan.

Hasil penelitian ini bertolak belakang dengan penelitian (Ansong dan Gyensare, 2012, Taylor dan Wegland, 2009) dan Wagland dan Taylor (2009) yang menjelaskan bahwa laki-laki lebih pandai dalam mengelola keuangan dibandingkan dengan perempuan serta mengindikasikan bahwa laki-laki lebih memiliki kepercayaan yang tinggi dalam membuat keputusan keuangan dibandingkan dengan perempuan yang lebih cenderung risk averse dibandingkan dengan laki-laki. Lebih lanjut rendahnya kepercaan diri perempuan juga disebabkan oleh peranannya sebagai ibu

\section{Simpulan}

Berdasarkan analisis yang telah didapatkan, maka dapat disimpulkan pembelajaran manajemen keuangan berpengaruh positif dan signifikan terhadap perilaku berinvestasi pada mahasiswa Magister Manajemen Universitas Pamulang. Sementara gender tidak memoderasi pengaruh pembelajaran manajemen keuangan terhadap perilaku berinvestasi pada mahasiswa Magister Manajemen Universitas Pamulang. Sementara penulis memberikan saran diharapkan penelitian ini dapat dijadikan sebagai acuan agar dosen mata kuliah manajemen keuangan untuk lebih meningkatkan kinerja dalam pembelajaran sehingga tujuan pembelajaran dapat dipraktekkan dalam kehidupan seharihari, terutama digunakan untuk mengelola keuangan dengan baik.

\section{References}

Cahya, A. D., \& Wahono, F. X. (2017). Perspektif Pembelajaran Berinvestasi Pasar Modal dengan Stimulus Free Opening di Galeri Investas Universitas Sarjana Wiyata Taman Siswa. Jurnal Online Ekonomi Bisnis dan Manajemen Daulat Rakyat, 1

Cooper, Donald R.C. dan Emory, William. (1998). Metode Penelitian Bisnis. Erlangga, Jakarta

Croushore, Dean. (2006). Money and Banking: A Policy Oriented Approach. New York:Cengage Learning.

Hanafy, M. S. (2014). Konsep Belajar dan Pembelajaran. Lentera Pendidikan, 7, 66-79.

Hermawati, N. R., \& Mudhofar, M. (2018). Analisis Faktor- Faktor Yang Mempengaruhi Minat Mahasiswa Untuk Berinvestasi di Pasar Modal (Studi Pada Mahasiswa Prodi Akuntansi STIE Widya Gama Lumajang). Progress Conference, 1.

Ismayanti, I. (2020). Pengaruh Love of Money dan Financial Knowledge terhadap Personal Financial Management dengan Gender sebagai Variabel Moderasi pada Generasi Millennial di Kota Makassar (Doctoral dissertation, Universitas Islam Negeri Alauddin Makassar).

Izza, M. Y. (2020). Pengaruh Pendapatan, Literasi Keuangan, Gaya Hidup Terhadap Pengelolaan Keuangan Pribadi Dengan Gender Sebagai Variabel Moderasi (Doctoral dissertation, STIE Perbanas Surabaya).

Janor, H., Yakob, R., Hashim, A. N., Zanariah, Z., \& Wel, C. A. (2017). Financial Literacy and Investment Decisions in Malaysia and United Kingdom : A Comparative Ananlysis. Malaysian Journal of Society and Space, 12(2). 
Kumala, A. N. (2019). Pengaruh Pembelajaran Manajemen Keuangan, Literasi Keuangan, Risk Tolerance Terhadap Perilaku Berinvestasi Mahasiswa Fakultas Ekonomi Universitas Negeri Surabaya. Jurnal Pendidikan Akuntansi, 197-203.

Maghfiroh, I. (2021). Pengaruh literasi keuangan dan perilaku keuangan terhadap minat investasi dengan gender sebagai moderasi: Studi pada keluarga di Kota Malang (Doctoral dissertation, Universitas Islam Negeri Maulana Malik Ibrahim).

Markowitz, H. (1952). Portofolio selection. The Journal of Finance, 45 (1), 31 - 42.

Nurvitasari, D., \& Rita, M. R. (2020). Confirmation Bias dalam Keputusan Investasi Dana Pensiun dengan Moderasi Gender. Jurnal Visi Manajemen (JVM), 5(2).

Pradikasari, E., \& Isbanah, Y. (2018). Pengaruh Financial Literacy, Illusion of Control, Overconfidence, Risk Tolerance, dan Risk Perception Terhadap Keputusan Investasi pada Mahasiswa di Kota Surabaya. Jurnal Ilmu Manajemen Universitas Negeri Surabaya, 424-434.

Puji, P. S., \& Hakim, L. (2021). Peran Gender sebagai Variabel Moderating Pembelajaran Perbankan Syariah, Literasi Keuangan Syariah, Religiusitas, Inklusi Keuangan Syariah Terhadap Minat Menabung Bank Syariah. Jurnal Pendidikan Akuntansi (JPAK), 9(1), 1-12.

Rasheed, M., H., et. al. (2016). Factors influencing investor's decision making in Pakistan. Review of Behavioral Finance, 10(1), $70-87$.

Sasongko, Sri Sundari. 2009. Konsep dan Teori Gender. Jakarta: Pusat Pelatihan Gender dan Peningkatan Kualitas Perempuan BKkbN

Sucianah, A., \& Yuhertiana, I. (2021). Gender Memoderasi Financial Literacy Dan Financial Behavior Terhadap Ketahanan Keuangan Rumah Tangga Milenial Selama Pandemi Covid-19. Jurnal Proaksi, $8(2), 127-137$.

Sugiyono, (2008). Metode Penelitian Kuantitatif Kualitatif dan R\&D. Bandung Alfabeta.

Syahyunan. (2015). Analisis Investasi. Medan: USU Press.

Syahyunan. (2015). Manajemen Keuangan. Medan: USU Press.

Tanusdjaja, H. (2018). Keputusan Investasi Investor Individu Berdasarkan Kompetensi, Overconfidence, dan Pendidikan. 234-244.

Trifani, A. B. (2020). Pengaruh Literasi Keuangan Terhadap Financial Risk Taking Dengan Perilaku Machiavelli Sebagai Variabel Moderasi (Doctoral dissertation, Universitas Airlangga).

Widayat. (2011). Perilaku Berinvestasi Perspektif Mixed Method. Aditya Media,11(4)

Yulinar, B., \& Umrie, R. H. (2020). Literasi Keuangan dan Kepuasan Keuangan dengan Gender sebagai Moderasi: Studi pada Mahasiswa di Kota Palembang. Jurnal Manajemen dan Bisnis Equilibrium, 6(1), 116.

Yunita, N. (2020). Pengaruh Gender Dan Kemampuan Akademis Terhadap Literasi Keuangan Dalam Perilaku Pengelolaan Keuangan Pada Mahasiswa Jurusan Akuntansi. Prisma (Platform Riset Mahasiswa Akuntansi), 1(2), 1-12. 